Science and Humanities Journal

Vol. 10, 2013, pp. 83-97 Dol: https://doi.org/10.47773/shj.1998.101.5

\title{
FIBER MORPHOLOGICAL PROPERTIES OF THREE PROMISING ABACA (Musa textilis Nee) CULTIVARS
}

\author{
Luz O. Moreno \\ Associate Professor; National Abaca Research Center. \\ Visayas State University Visca, Baybay' City 6521-A \\ Leyte, Pbilippines
}

\begin{abstract}
The fiber morphological properties of three promising abaca (Musa textilis Nee) cultivars found in the abaca germplasm collection of the National Abaca Research Center were investigated to assess their suitability for pulp and paper production. It was found that Inosa produced the longest fibers $(4.58 \mathrm{~mm})$ followed by Laylay $(3.43 \mathrm{~mm})$, while Gomez hybrid had the shortest $(2.45 \mathrm{~mm})$. The three cultivars did not vary in fiber cell diameter, lumen width and cell wall thickness. Tensile strength of Inosa was highest at $84.68 \mathrm{cN} /$ tex compared to Laylay (69.27 cN/tex) while Gomez hybrid had the lowest at $25.65 \mathrm{cN} /$ tex). The very high tensile strength of Inosa as well as its high slenderness and runkel ratios make it very suitable for the production of high quality pulp and paper. Slenderness and runkel ratios of the Gomez hybrid were the lowest while its flexibility ratio was the highest indicating poor fiber quality. Such properties, however, still make its fibers acceptable for low-grade pulp and paper products such as newsprint paper production.
\end{abstract}

Key words: tensile strength, fiber properties, fiber morphology, pulp and paper, Gomez hybrid 


\section{INTRODUCTION}

Abaca (Musa textilis Nee) or Manila hemp in international trade, is indigenous to the Philippines. It is one of the major export crops of the country. The Philippines is the abaca capital of the world supplying more than $85 \%$ of the total world abaca fiber requirement annually while the remaining $15 \%$ is supplied by Ecuador (FiDA, 2009; Philexport, 2010). The abaca industry continues to make a stronghold in both domestic and international markets generating an average of US\$80M annually from 1996-2000 (FiDA, 2010).

Abaca is considered as the strongest of all natural fibers. It is actually a leaf or bast fiber (Joseph, et al., 2002), composed of long slim cells that form part of the leaf's supporting structure. The cellulosic fibers are obtained from the pseudostem. Abaca fiber is prized for its great mechanical strength, buoyancy, resistance to saltwater damage, and long fiber length of up to $3 \mathrm{~m}$. The best grades of abaca are fine, lustrous, light beige in colour and very strong. Musa textilis Nee produces high quality fibers and paper sheets of acceptable strength-related properties (breaking length, stretch and tear index), good yields and potential savings in capital equipment costs (Jimenez et al., 1993).

Abaca offers great potential as raw material for different industrial applications due to its unique fiber characteristics. Its superior tensile strength and extremely long fibers compared with other natural fiber sources makes it more desirable as composites even in highly stressed components in the car manufacturing industry. Compared with synthetic fibers like rayon and nylon, abaca fiber has higher tensile strength and lower elongation in both wet and dry states (Isarog, 2005). This establishes the fact that natural fiber has better characteristics than the common man-made fibers. When converted to pulp, the fiber finds extensive use in specialty paper making, where the principally desired characteristics are good strength and porosity, and in general, substantial wet strength. The high ratio of fiber length and fiber width partially explains the remarkable properties of abaca pulp. 
With the increasing advances in technology development, the abaca fiber has been found to have new and varied uses. The utilization of the abaca fiber for pulp and paper production, as composite in the car manufacturing industry, for other industrial uses and for various handicraft products with local and export market potentials are indications of the bright prospects of the abaca industry. Each of these different industrial applications require specific fiber properties, hence there is a need to characterize the fiber morphological properties of promising abaca cultivars.

\section{MATERIALS \& METHODS}

\section{Selection of the Abaca Varieties}

Abaca varieties Inosa and Laylay were used in this study since these are the recommended and widely grown high yielding varieties in the Visayas with fibers suited for the pulp and paper, cordage and fibercraft industries. Moreover, Inosa and Laylay are used as the standard check varieties as basis for comparison in terms of fiber yield and fiber qualities (NARC, 2008). The wild type, Gomez hybrid was also included on the basis of its tensile strength being grouped together with the wild collection of the National Abaca Research Center (NARC), Visayas State University (VSU), Visca, Baybay, Leyte, and the availability of fibers during the conduct of this study.

\section{Harvesting and Stripping of Fibers}

Mature stalks of Inosa, Laylay and Gomez hybrid were harvested from the germplasm collection of NARC, VSU, Visca, Baybay, Leyte. Index to maturity of the plant is shown by the appearance of the flagleaf. The fibers were stripped using a spindle stripping machine with a zero serration blade. 
meter (Zwick \& Co., Kommand, Gosollach, Einsingen b. Ulm). The strength force was expressed in centi-Newton to break a bundle of fiber one tex unit size or $\mathrm{cN} /$ tex. An average of ten sample fiber strands were used. Tensile strength was computed using the formula;

$$
\text { Tensile Strength (TS) }=\frac{\text { Breakingload } \times \text { Length }}{\text { Weight of fiber }}
$$

Fiber cell length ( $\mathrm{mm}$ ) was measured by getting the entire length of the fiber as viewed under the microscope with an ocular micrometer. Fiber cells are elongate cells with tapering ends.

Fiber cell diameter ( $\mathrm{mm}$ ) was measured at the median portion of the cell. This is the largest distance formed between opposite ends of the cell wall (Figure 1). Cell wall thickness (mm) measures the thickness of the cell walls and computed as;

$$
\text { Cell wall thickness }=\frac{\text { Cell diameter }- \text { cell lumen }}{2}
$$

Favorable pulp strength properties are obtained when the runkel ratio is lower than the standard value of 1.0. Lower runkel ratio indicates stronger burst and folding strength. Higher flexibility ratio reflects more flexible fibers while higher slender ratio indicates higher resistance to tearing and computed as;

$$
\text { Runkel Ratio }(R R)=\frac{2 X \text { cell wall thickness }}{\text { Lumen width }}
$$

Flexibility Ratio $(F R)=\underline{\text { Lumen width }} \times 100$

Diameter

$$
\text { Slender Ratio }(S R)=\frac{\text { Cell Length }}{\text { Diameter }}
$$




\section{Preparation of Fiber Samples for Morphological Properties Determination}

Fiber hanks taken from the middle leaf sheaths were divided into the butt, middle and tip portions then cut into $2-3 \mathrm{~cm}$ long fibers and then immersed in freshly prepared macerating solution consisting of $1: 110 \%$ aqueous chromic acid and $10 \%$ aqueous nitric acid for 24 hours (Jeffrey's Method, Baluyot, 2000). For the wild hybrid, soaking in macerating solution was only for eight hours. When the fibers could be readily separated, these were washed thoroughly with tap water at least three to four times, to remove the acid After washing, these were immediately stained with $1 \%$ Safranin O in $50 \%$ ethyl alcohol (EtOH) for 12 to 24 hours and dehydrated in 50\% $\mathrm{EtOH}, 70 \% \mathrm{EtOH}, 85 \%$ EtOH and 95\% EtOH for 10 minutes each, then cleared in 1:1:1 Xylene, Aniline and 95\%EtOH, 2:1 Xylene and Aniline, 3:1 Xylene and Aniline, Xylene I (Pure Xylene) and Xylene II (Pure Xylene). After the last series of clearing using Xylene II, the fibers were ready for manual maceration. A small piece of fiber tissue was placed on a clean glass slide then slowly and gently macerated until individual fiber strands were completely separated. Macerated fiber tissue was observed under a compound microscope. Permanent slide mounts of good quality macerated fibers were prepared using two to three drops of Canada balsam.

The cell length, cell diameter and cell lumen width were directly measured under the microscope through the microfilar eyepiece. The length of individual fiber cells was measured using a compound microscope with an ocular micrometer. Sixty (60) readings as recommended by Paje et al. (1991) and Tabora (1976) were done per entry with 20 readings per replicate for each of the parameters.

Tensile Strength (cN/tex), defined as the resistance of a material to a force tending to tear it apart, was measured as the maximum tension the material can withstand without tearing (www.answers.com/topic/tensile-strength). It was determined by cutting $12 \mathrm{~cm}$ long fiber samples from about $50 \mathrm{~cm}$ distance from the butt end of the dried fiber taken from the middle leaf sheath of the sample plant. Each fiber strand was weighed in an analytical balance and breaking load was measured using an analogue tensile strength 


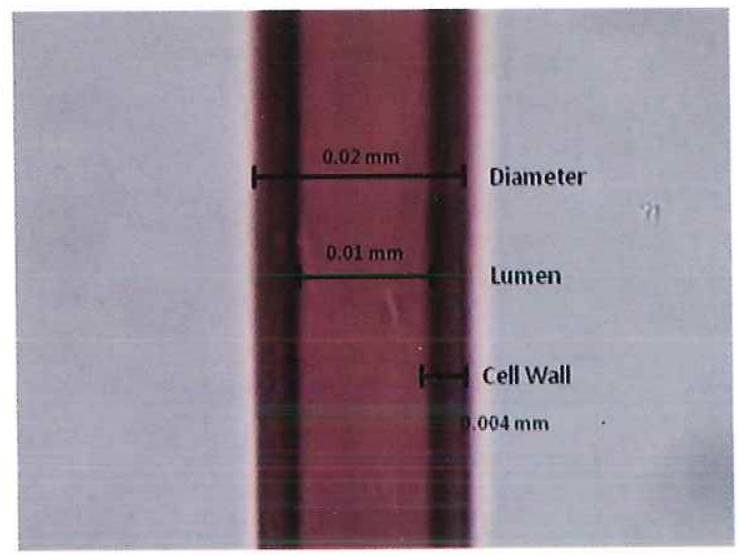

Figure 1. Longitudinal section of an abaca fiber cell structure, $400 \mathrm{X}$

\section{RESULTS AND DISCUSSION}

\section{Morphological Characteristics of Selected Fibers}

Length of individual fiber cells was significantly different among the three abaca varieties. Inosa had the longest fibers measuring $4.5857 \mathrm{~mm}$ followed by Laylay $(3.433 \mathrm{~mm}$ ) and Gomez hybrid having the shortest fibers measuring only $2.4467 \mathrm{~mm}$ (Table 1). Gomez hybrid also had the lowest tensile strength of $25.65 \mathrm{cN} /$ tex (Table 3) while Inosa has the highest tensile strength of $84.68 \mathrm{cN} /$ tex, indicating that fiber length is related to tensile strength (Oluwadare et al., 2007).

Cell diameter, lumen width and cell wall thickness did not significantly differ among the three abaca varieties. However, Inosa and Laylay showed relatively thicker cell walls and smaller lumen width compared to those in the Gomez hybrid (Figure 2). 
Table 1. Fiber cell morphology of abaca (Musa textilis Nee) varieties Inosa and Laylay (Gomez hybrid).

\begin{tabular}{lcccc}
\hline \multicolumn{1}{c}{ Variety } & $\begin{array}{c}\text { Cell Length } \\
(\mathbf{m m})\end{array}$ & $\begin{array}{c}\text { Cell } \\
\text { Diameter } \\
(\mathbf{m m})\end{array}$ & $\begin{array}{c}\text { Lumen } \\
\text { Width } \\
(\mathbf{m m})\end{array}$ & $\begin{array}{c}\text { Cell Wall } \\
\text { Thickmess } \\
(\mathbf{m m})\end{array}$ \\
\hline & & & & \\
Inosa & $4.5857 \mathrm{a}$ & 0.0201 & 0.0117 & 0.0042 \\
Lavlay & $3.4337 \mathrm{~b}$ & 0.0190 & 0.0111 & 0.0040 \\
Gomez Hybrid & $2.4467 \mathrm{c}$ & 0.0221 & 0.0159 & 0.0031 \\
CV (\%) & 4.27 & 3.71 & 6.54 & 7.88 \\
\hline Mean values with the same letters are not significantly different at $p=0.05$ (LSD)
\end{tabular}

Mean values with the same letters are not significantly different at $p=0.05$ (LSD)

Table 2. Slenderness, flexibility and runkel ratios of abaca (Musa textilis Nee) varieties Inosa and Laylay (Gomez hybrid).

\begin{tabular}{lccc}
\hline \multicolumn{1}{c}{ Varietv } & Slenderness Ratio & Fexibility Ratio & Runkel Ratio \\
\hline Inosa & $228.52 \mathrm{a}$ & $58.14 \mathrm{~b}$ & $0.7200 \mathrm{a}$ \\
Laylay & $180.72 \mathrm{~b}$ & $58.25 \mathrm{~b}$ & $0.7169 \mathrm{a}$ \\
Gomez Hybrid & $110.88 \mathrm{c}$ & $71.90 \mathrm{a}$ & $0.3908 \mathrm{~b}$ \\
& & & \\
CV (\%) & 4.27 & 4.27 & 9.92 \\
\hline Mean values with the same letters are not significantly different at $p=0.05$ (LSD)
\end{tabular}

Table 3. Fiber yield, fiber recovery and tensile strength of abaca (Musa textilis Nee) varieties Inosa and Laylay and wild relative (Gomez hybrid).

\begin{tabular}{lccc}
\hline \multicolumn{1}{c}{ Variety } & $\begin{array}{c}\text { Fiber Yield } \\
\text { (gms/plant) }\end{array}$ & $\begin{array}{c}\text { Fiber Recovery } \\
\text { (\%) }\end{array}$ & $\begin{array}{c}\text { Tensile Strength } \\
\text { (cN/tex) }\end{array}$ \\
\hline Inosa & $293.89 \mathrm{a}$ & $1.60 \mathrm{a}$ & $84.68 \mathrm{a}$ \\
Laylay & $266.04 \mathrm{a}$ & $1.42 \mathrm{~b}$ & $69.27 \mathrm{~b}$ \\
Gomez Hybrid & $34.67 \mathrm{~b}$ & $0.20 \mathrm{c}$ & $25.65 \mathrm{c}$ \\
CV (\%) & 11.69 & 1.37 & 4.85 \\
\hline
\end{tabular}

Mean values with the same letters are not significantly different at $p=0.05$ (LSD). 
The fiber cells of abaca are 3.0-15 mm long and $3.0-30 \mu \mathrm{m}$ in diameter, with a lumen width of about $3.0 \mu \mathrm{m}$ (Wood, 1981). Longitudinally, the fibers are tapering gradually to a pointed or rounded end (Figure 2d) (Sinon, 2008; Kohler, 2006; Bawagan et al., 1970). Fiber cells have large lumen and sometimes, relatively thin cell walls (Figure 2).

Slenderness ratio of Inosa was significantly highest at 228.52, followed by that of Laylay with Gomez hybrid having the lowest (Table 2). A high slenderness ratio indicates that the material is very good for pulp having satisfactory pulp tear indices and bursting strengths necessary for printing and writing purposes (Batra, 1985; Sun, 1998). Although the Gomez hybrid had the significantly lowest slenderness ratio, it had the significantly highest Flexibility ratio and lowest Runkel ratio. This means that Gomez hybrid can yield pulps with acceptable breaking length, tear and burst indices suitable for newsprint paper production (Jiminez et al., 1993: Cappelletto et al., 2000). This probably explains why fibers of wild types and relatives of abaca can still be used for low grade pulp and paper products.

The importance of fiber dimensions and their derived values (slenderness ratio, flexibility coefficient and Runkel ratio) on pulp and paper mechanical strength is well documented. Seth and Page (1988) as cited by Law et al. (2001) have shown that under certain conditions, tearing resistance depends strongly on fiber length, whereas Horn (1978) and Scott et al., (1995) reported that increase in raw material fiber length enhances the tearing strength of hardwood pulps. Using multiple regression analysis, Horn and Setterholm (1990) found that the majority of variation in burst and tensile strength in hardwood pulpsheets could be accounted for by fiber length and cell wall thickness. Kellogg and Thykeson (1975) and Matolcsy (1975) have also pointed out the significance of fiber dimensions in predicting wood pulp mechanical properties.

Fiber yield of Inosa and Laylay varieties were significantly higher compared to that of Gomez hybrid (Table 3). The significant difference in fiber yield and fiber recovery between those of the check varieties and Gomez hybrid was four to five times higher. The very low fiber yield and fiber recovery of Gomez hybrid were due primarily to its significantly low tensile strength. During the stripping process, 
only a small amount of fibers may have been recovered as most are weak and would break and remain in the tuxy (outermost portion of the leaf sheath where the fibers are extracted) along with the stripping wastes.

Gomez hybrid was originally collected from Trento, Agusan del Sur. There is no record or literature available regarding the progenitors or parents of this accession. It was named Gomez hybrid because it was reportedly first cultivated for commercial production by a certain Engr. Gomez. (as per communication from the people in the area where it was collected). Gomez hybrid was not adopted for commercial planting due to its very weak fibers. However, its fibers can still be used as raw material for production of low grade pulp because of its good flexibility and Runkel ratios, which can yield pulps with acceptable breaking length, tear and burst indices (Jimenez et al, 1993; Cappelletto et al., 2000) suitable for newsprint paper production.

\section{Specific End Uses and Breeding Research}

Abaca varieties Inosa and Laylay are the recommended high yielding varieties in the Visayas, particularly in Region 8 . There fibers have very high tensile strength, hence suited for the cordage, pulp and paper industries. Inosa is best for the production of high end quality pulp due to its high pulp recovery and excellent pulping characteristics. Laylay is suited for the fibercraft industry because of its lustrous, ivory white and uniform fiber strands from tip to the base, which do not easily tangle (NARC, 2008).

Gomez hybrid is a highly suckering wild relative of abaca with big stalks at maturity. Fiber extraction can be done by decorticating method or hand stripping using 16 to 24 serration blade to get higher fiber yield. It can be used as source of fibers for the production of low grade quality pulp. In view of the shortage of conventional raw materials for pulping and the increasing demand for paper products worldwide (Ververis et al., 2004), non-woody plants like abaca can offer several advantages including shorter growth cycles compared with pulp wood source, moderate fertilization requirement and low lignin content resulting to reduced energy and chemical use during pulping (Hurter and Riccio, 1998). 
The extensive abaca germplasm collection of the NARC, Visayas State University Visca, Baybay City, Leyte has not been thoroughly explored in terms of fiber usage and applications for the pulp and paper industry.

The fiber morphology and dimensions of Gomez hybrid could represent the fiber quality of the wild types and relatives of abaca present in the germplasm collection of NARC. These materials offer great potential and therefore needs to be investigated by the researchers of the institution especially in their breeding programs.

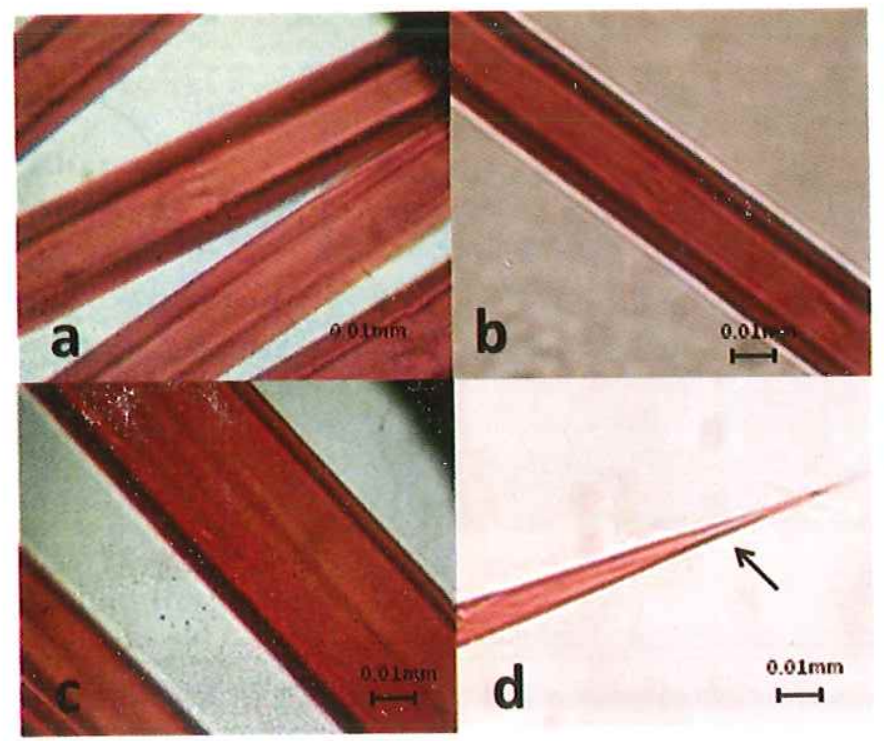

Figure 2. Fiber cells of abaca varieties Inosa (a) and Laylay (b) showing thick cell walls and thinner lumen width and Gomez hybrid with thin cell walls and bigger lumen size (c) 400X. Tapering to pointed tip of a fiber cell of Laylay (d) $100 \mathrm{X}$. 


\section{CONCLUSION AND RECOMMENDATIONS}

Gomez hybrid has the shortest fibers while Inosa had the longest. All three varieties have comparable fiber cell diameter, lumen width and cell wall thickness. Tensile strength of Inosa was highest followed by Laylay while Gomez hybrid has the lowest. The very high tensile strength and high slenderness and runkel ratios of Inosa make it very suitable for the production of high quality pulp. Slenderness and runkel ratios of the Gomez hybrid were lowest while its flexibility ratio was the highest indicating poor fiber quality for high end quality pulp products. However, compared to fibers from wood pulps, the fibers of Gomez hybrid are still highly acceptable for pulp and paper production.

Based on the results of this study, it can be inferred that Gomez hybrid is suitable for the production of low grade quality pulp while Inosa and Laylay are suitable for high grade pulp production.

It is recommended that extensive studies of the same nature be conducted to the other existing wild abaca collections of the National Abaca Research Center, Visayas State University, Visca, Baybay, Leyte.

\section{ACKNOWLEDGMENT}

The author is grateful to the National Abaca Research Center, Visayas State University, Visca, Baybay City, Leyte through its director, Dr. Ruben M. Gapasin for allowing her to get fiber samples used in the study, Ms. Ammie Parac, Felix L. Ocon and Mr. Mario A. Valenzona for some important information and other secondary data and $\mathrm{Mr}$. Patricio Barbosa for harvesting and stripping the fibers.

The author is also thankful to the Institute of Biological Sciences, University of the Philippines, Los Banos, Laguna for allowing her access to the laboratory facilities especially to Mr. Alex Fajardo for the assistance in taking photomicrographs. 


\section{LITERATURE CITED}

AMIDON, T.E. 1981. Effect of wood properties of hardwood on kraft paper properties. Technical Association of the Pulp and Paper Industry (TAPPI), 64:123-126.

BAWAGAN, B.O., E.M. MIDRANO AND E.P. VILLANUEVA. 1972. High Alpha Pulp from Abaca (Musa textilis Nee) Fibers. For Leaves, 8:8.

BATRA, S.K. 1985. Other Long Vegetable Fibers: Abaca, Banana, Sisal, Henequen, Flax, Ramie, Hemp. Sunn, and Coir. In: Handbook of Fiber Science and Technology. M. Lewin and E.M. Pearce, eds. pp. 728-791. Marce 41 Dekker, Inc. New York.

CAPPELLETTO, P., F. MONGARDINI. B. BARBERI, B. SANNIBALE, M. BRIZZI AND V. PIGNATELLI. 2000. Papermaking pulps from the fibrous fraction of Miscanthus $x$ giganteus. Ind. Crops Prod. 11: 205-210.

HORN, R. A.. 1974. Morphology of pulp fiber from softwoods and influence on paper strength. USDA Forest Service. Research Paper FPL 242, Forest Products Laboratory, Madison, WI, USA.

HORN, R.. A. AND V.C. SETTERHOLM. 1990. Fiber morphology and new crops. In: Janick, J., Simon, J.E. (eds.). Advances in New Crops. Timber Press. Portland, OR. pp. 270-275.

HURTER, R.W. AND F.A. RICCIO. 1998. Why CEOs don't want to bear about non-woods - or should they? In: Technical Association of the Pulp and Paper Industry (TAPPI) Proceedings, Non-wood Fiber Symposium, Atlanta, GA, USA, pp.1-11. 
ISAROG PULP AND PAPER CO. INC. 2005. The Abaca Fiber and the Pulp. http:/www.isarogpulp.com/origin.html.

JIMENEZ, L.A., F.L. BALDOVIN AND J.L.F. HERRANZ. 1993. Evaluation of agricultural residues for paper manufacture. TAPPI Journal. 76(3):169-173.

JOSEPH, S., M.S. SREEKALA, Z. OOMMEN, P. KOSHYY AND S. THOMAS. 2002. A comparison of the mechanical properties of phenol formaldehyde composites reinforced with banana and glass fibers. Composites Science and Technology, 62:1857-1868.

KELLOGG, R.M. AND E. THYKESON. 1975. Predicting kraft mill paper strength from fiber properties. TAPPI Journal 58(4): 131-135.

KOHLER, R. 2006. Preliminary Results on the Use of Abaca Fiber for Automotive Application. Institut fur Angewandte Forschung, University of Applied Sciences:Alteburgstr, 150, D-72762 Reutlingen. p.16.

LAW, K.N., B.V. KOKTA AND C.B. MAO. 2001. Fiber morphology and soda-sulphite pulping of switchgrass. Bioresource Technology 77:1-7.

MATOLCSY, G.A. 1975. Correlation of fiber dimensions and wood properties with the physical properties of kraft pulp of Abies balsamea L. (Mill.). TAPPI Journal 58(54): 136-141.

NARC ANNUAL REPORT. 2008. National Abaca Research Center, Visayas State University, Visca, Baybay, Leyte. Unpublished Report. 52pp. 
WANGAARD, F.F. AND G.E. WOODSON. 1973. Fiber length and fiber strength in population of kraft pulps produced from a diverse hardwood species. Wood Science, 5:235-240.

WOOD, J.M. 1981. The utilization of field crops and crop residues for paper pulp production. Field Crop Abstracts, 34:557-568. 
OLUWADARE, A. OLUWAFEMI AND O. ASHIMIYU SOTANNDE. 2007. The relationship between fiber characteristics and pulp sheet properties of Leucaena leucocephala (Lam.) De Wit. Middle East Journal of Scientific Research 2(2):63-68.

PAJE, L.P., A.A. BONDAD AND I.S. ANUNCIADO. 1991. Some factors affecting the cellulose and lignin contents of abaca fibers. UPLB Basic Research No. 80-11. Project SemiAnnual Report, Jan-June 1981.

PANSHIN, J. AND C. DE ZEEUW. 1980. Textbook of Wood Technology (4 $4^{\text {th }}$ edition) McGrawhill, New York, pp. 772 .

SCOTT, W.E., J. ABBOTT AND S. TROSSET. 1995. Properties of Paper. An Introduction. TAPPI Press, Atlanta, GA, USA.

SINON, F. 2008. Optimization of Stripping Technologies for the Production of High Quality Abaca Fiber. PhD Dissertation. Faculty of agricultural Sciences, Institute for Agricultural Engineering. University of Hohenheim, Germany p 130.

SUN, R. 1998. Fractionation and characterization of polysaccharides from abaca fiber. Carbohydrate Polymers, 37(4): 351-359.

TABORA, P. C. Jx. 1976. Morphology of Abaca (Musa textilis Nee) Fibers at Vegetative Stages of Stalk Development. Unpublished MS Thesis. UPLB, College, Laguna.

VERVERIS, C., K. GEORGHIOU, N. CHRISTODOULAKIS, P. SANTAS AND R. SANTAS. 2004. Fiber dimensions, lignin and cellulose content of various plant materials and their suitability for paper production. Industrial Crops and Products 19: 245-254. 